\title{
Protective effect of arctigenin on ethanol-induced neurotoxicity in PC12 cells
}

\author{
JIA HUANG $^{1 *}$, LAN XIAO $^{1 *}$, JING-XIANG WEI $^{1}$, YA-HAI SHU ${ }^{1}$, \\ SHI-QI FANG ${ }^{1}$, YONG-TANG WANG ${ }^{2}$ and XIU-MIN LU ${ }^{1}$ \\ ${ }^{1}$ College of Pharmacy and Bioengineering, Chongqing University of Technology, Chongqing 400054; \\ ${ }^{2}$ State Key Laboratory of Trauma, Burns and Combined Injury, Institute of Surgical Research, \\ Daping Hospital, Third Military Medical University, Chongqing 400042, P.R. China
}

Received December 5, 2015; Accepted November 30, 2016

DOI: $10.3892 / \mathrm{mmr} .2017 .6222$

\begin{abstract}
As a neurotropic substance, ethanol can damage nerve cells through an increase in the production of free radicals, interference of neurotrophic factor signaling pathways, activation of endogenous apoptotic signals and other molecular mechanisms. Previous studies have revealed that a number of natural drugs extracted from plants offer protection of nerve cells from damage. Among these, arctigenin (ATG) is a lignine extracted from Arctium lappa (L.), which has been found to exert a neuroprotective effect on scopolamine-induced memory deficits in mice with Alzheimer's disease and glutamate-induced neurotoxicity in primary neurons. As a result, it may offer beneficial effects on ethanol-induced neurotoxicity. However, the effects of ATG on ethanol-induced nerve damage remain to be elucidated. To address this issue, the present study used rat pheochromocytoma PC12 cells to investigate the neuroprotective effects of ATG on ethanol-induced cell damage by performing an MTT reduction assay, cell cycle analysis, Hoechst33342/propidium iodide fluorescence staining and flow cytometry to examine apoptosis. The results showed that $10 \mu \mathrm{M}$ ATG effectively promoted the proliferation of damaged cells, and increased the distribution ratio of the cells at the $\mathrm{G} 2 / \mathrm{M}$ and $\mathrm{S}$ phases $(\mathrm{P}<0.05)$. In addition, the apoptosis and necrosis of the $\mathrm{PC} 12$
\end{abstract}

Correspondence to: $\mathrm{Dr}$ Xiu-Min Lu, College of Pharmacy and Bioengineering, Chongqing University of Technology, 69 Hongguang Avenue, Banan, Chongqing 400054, P.R. China E-mail: luxm@cqut.edu.cn

Dr Yong-Tang Wang, State Key Laboratory of Trauma, Burns and Combined Injury, Institute of Surgical Research, Daping Hospital, Third Military Medical University, 10 Changjiang Sub-Road, Yuzhong, Chongqing 400042, P.R. China

E-mail:wangytlu@163.com

*Contributed equally

Key words: arctigenin, protective effect, ethanol-induced neurotoxicity, $\mathrm{PC} 12$ cells cells were significantly decreased following treatment with ATG. Therefore, it was concluded that $10 \mu \mathrm{M}$ ATG had a protective effect on ethanol-induced injury in PC12 cells.

\section{Introduction}

As a neurotropic substance, ethanol can damage nerve cells through increasing the production of free radicals, interference of neurotrophic factor signaling pathways, activation of endogenous apoptotic signals and other molecular mechanisms $(1,2)$. Alcohol abuse has become a public health issue (3). In 2014, a World Health Organization survey estimated that $\sim 3,300,000$ individuals in 2012 succumbed to alcohol consumption-associated mortality, of which $\sim 132,000$ were directly associated with neuropsychiatric disorders (4). Chronic alcoholism is a common worldwide disease and risks to human health are worsening. Increasing evidence indicates that alcoholism can reduce cell numbers in several neuronal populations within the developing brain, including the hippocampus, cerebellum and cortex (5-7).

There are several drugs, which are currently used for the clinical treatment of nerve damage caused by alcohol, including naloxone for acute alcoholism, meclofenoxate as a central nervous system stimulant, D-Ala2-met-enkephalinamide and ondansetron, which can prevent alcoholism by reducing ethanol intake (8). However, these drugs are not adequate for the treatment of chronic nerve damage caused by alcoholism, and $90 \%$ of alcoholic patients may have used aversive drugs during a certain period of the treatment (9). As a result, it is important to identify and develop novel drugs, which promote neuronal cell regeneration or inhibit apoptosis for the treatment of alcohol-induced nerve injury.

Arctigenin (ATG) is a type of lignin with low toxicity and few side effects, the chemical structure of which is shown in Fig. 1. It is the primary active constituent isolated from the fruit of Arctium lappa L. ATG has been reported to possess several bioactivities and a number of important pharmacological properties, including antioxidant, antitumor, anti-inflammatory and immunomodulatory effects (10-14). Previous studies have found that ATG provides a neuroprotective effect on cultured cortical neurons from glutamate-induced neurodegeneration and acts on scopolamine-induced memory deficit 
in mice through mechanisms, which remain to be fully elucidated $(15,16)$. The present study aimed to investigate whether ATG promotes cell proliferation and inhibits apoptosis in ethanol-damaged PC12 cells, to determine whether ATG may be available for the clinical treatment of ethanol-induced neurotoxicity.

\section{Materials and methods}

Cell culture. The PC12 cells purchased from the Cell Bank of the Chinese Academy of Sciences (Shanghai, China) were grown in DMEM (Gibco; Thermo Fisher Scientific, Inc.) supplemented with $10 \%$ heat-inactivated $\mathrm{FBS}$, at $37^{\circ} \mathrm{C}$ in a $5 \% \mathrm{CO}_{2}$ humidified incubator. In all experiments, the cells were seeded at densities of 8,000 cells/well (96-well plate), $1 \times 10^{5}$ cells/well (24-well plate) or $2.5 \times 10^{5}$ cells/well (6-well plate). ATG was purchased from Sigma-Aldrich (St. Lous, MO, USA), dissolved in dimethyl sulfoxide (DMSO) and stored frozen until use. The treatment procedures were performed when the cells had adhered to the wall.

Measurement of cell viability. The protective effect of ATG on the ethanol-induced reduction of PC12 cell viability was detected using a conventional MTT reduction assay. The cells were seeded onto 96 -well plates at the density of 8,000 cells/well. On adhering to the wall, the cells were incubated with various concentrations of ATG $(0,1,5,10,30,50$ and $100 \mu \mathrm{M})$ and $500 \mathrm{mM}$ of ethanol for 24,48 and $72 \mathrm{~h}$ at $37^{\circ} \mathrm{C}$, respectively. In order to maintain a constant ethanol concentration, a methodology to deliver ethanol to the cultured cells was developed according to a method described by Adickes et al (17). Subsequently $10 \mu l$ of the MTT solution $(5 \mathrm{mg} / \mathrm{ml})$ was added to each well and incubated at $37^{\circ} \mathrm{C}$ for $4 \mathrm{~h}$. Finally, $150 \mu \mathrm{l}$ DMSO was added to each well and shaken for $10 \mathrm{~min}$ prior to removal of the medium. The absorbance was measured at $490 \mathrm{~nm}$ using an enzyme-linked immunosorbent assay. Cell viability was calculated by cell proliferation index as a percentage of the value against the control group. An untreated $\mathrm{PC} 12$ cell group was included and detected as a positive control.

Cell cycle analysis. PC12 cells cultured with $500 \mathrm{mM}$ ethanol, $10 \mu \mathrm{M}$ ATG, and $500 \mathrm{mM}$ ethanol combined with $10 \mu \mathrm{M}$ ATG were separately harvested by trypsinization and washed twice with cold PBS prior to fixation in $70 \%$ ethanol overnight at $4^{\circ} \mathrm{C}$. The cells were then incubated with RNase A $(100 \mu \mathrm{g} / \mathrm{ml}$; Fermentas; Thermo Fisher Scientific, Inc.) in PBS at $37^{\circ} \mathrm{C}$ for $30 \mathrm{~min}$. Propidium iodide (PI; $25 \mu \mathrm{g} / \mathrm{ml}$; Sigma-Aldrich; Merck Millipore, Darmstadt, Germany) was added at $4^{\circ} \mathrm{C}$ for $30 \mathrm{~min}$ in the dark. The cells were then detected using flow cytometry (FCM) with a BD FACSCalibur system (BD Biosciences, San Jose, CA, USA) and were analyzed at $488 \mathrm{~nm}$ excitation using ModFit software version 4.1 (Verity Software House, Inc., Topsham, ME, USA). At least 20,000 cells were analyzed in the cell sorting. The untreated PC12 cells were also analyzed as a positive control.

Hoechst33342/PI fluorescence staining. Following the treatments described above, the cells plated in 24-well plates were stained with $2 \mathrm{mg} / \mathrm{ml}$ Hoechst for $5 \mathrm{~min}$, followed by the addition of PI at a final concentration of $5 \mathrm{mg} / \mathrm{ml}$ for $10 \mathrm{~min}$. The

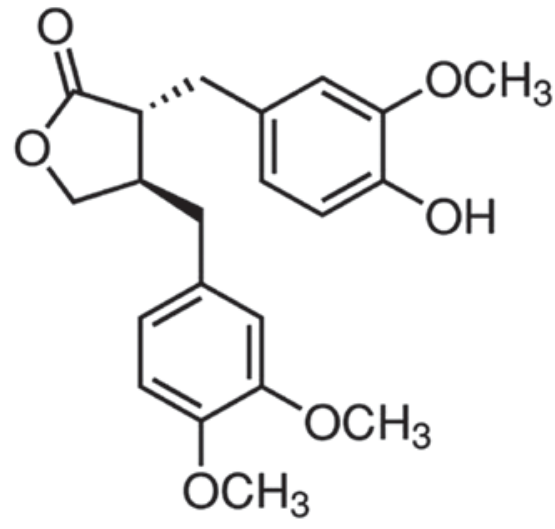

Figure 1. Chemical structure of arctigenin.

stained nuclei were observed using a fluorescence photomicroscope (Olympus, Tokyo, Japan). To evaluate the percentage of positive cells, four non-overlapping images were captured and at least 600 cells were calculated in each well.

FCM for analysis of apoptosis. The apoptotic rates were quantified using an Annexin V-PI apoptotic assay kit. Following the incubation with ATG and ethanol, the PC12 cells were harvested, washed twice with cold PBS, suspended in binding buffer, and incubated with PI and Annexin V-fluorescein isothiocyanate (FITC) for $30 \mathrm{~min}$ at room temperature. The samples were examined using FCM (BD FACSCalibur; BD Biosciences) and analyzed using the Cell Quest version 5.1 (BD Biosciences). At least 10,000 cells were collected in cell sorting.

Statistical analysis. Data obtained from the experiments are presented as the mean \pm standard error of the mean from at least three independent experiments. Statistical analyses were performed with SPSS version 10.0 (SPSS, Inc., Chicago, IL, USA) using one-way analysis of variance followed by Student's $t$-test. $\mathrm{P}<0.05$ was considered to indicate a statistically significant difference.

\section{Results}

ATG protects PC12 cells from ethanol-induced reduction of cell viability. Nerve cell regeneration is limited, and exposure to ethanol increases apoptosis and necrosis. As a result, it is essential to improve cell viability in the presence of ethanol in vitro. Therefore, the present study examined the protective effect of ATG on the ethanol-induced reduction of PC12 cell viability. Following treatment for 24,48 and $72 \mathrm{~h}$ with ethanol $(500 \mathrm{mM})$ and ATG $(1,5$ and $10 \mu \mathrm{M})$, cell proliferation rates were investigated using an MTT assay. As shown in Fig. 2A, the viability of the ethanol-treated cells increased significantly when treated with different concentration of ATG for 24, 48 and $72 \mathrm{~h}$, respectively $(\mathrm{P}<0.05)$. Treatment with ATG at a concentration of $10 \mu \mathrm{M}$ effectively promoted the viability of the ethanol-damaged cells.

Subsequently, the effect of ATG concentration on ethanol-damaged PC12 cells was investigated further. The PC12 cells were incubated with various concentrations of 
A

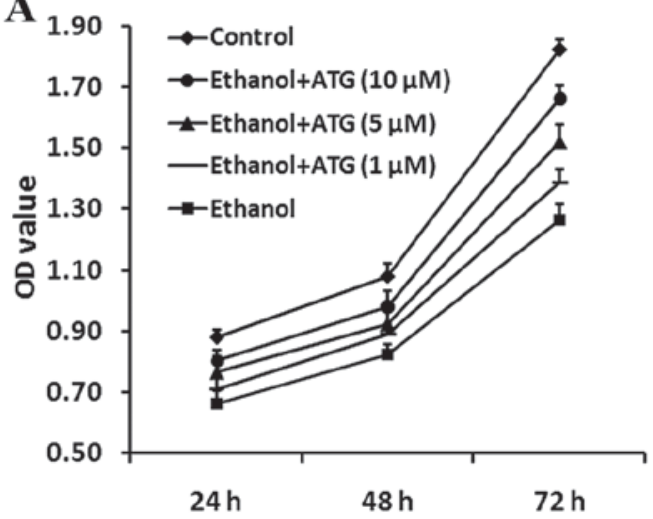

B

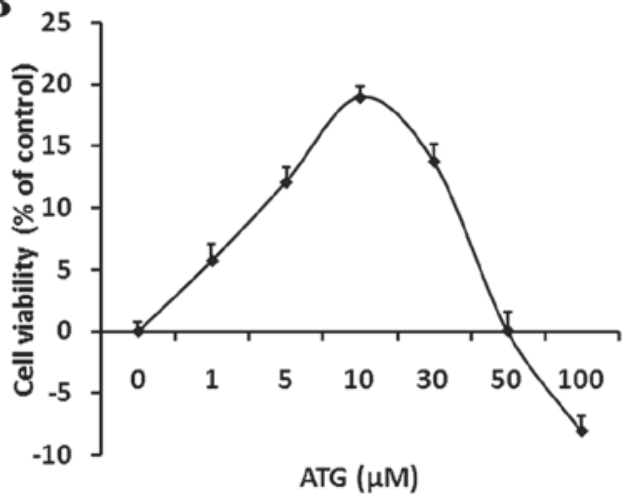

Figure 2. MTT assay of PC12 cells. (A) Proliferation of differently treated PC12 cells was assessed using an MTT assay. The proliferation of the ethanol-treated cells increased significantly when treated with different concentrations of ATG, with a concentration of $10 \mu \mathrm{M}$ effectively promoting the proliferation of damaged cells. Data are presented as the mean \pm standard error of the mean from a minimum of three independent experiments, ${ }^{*} \mathrm{P}<0.05$, vs. control; ${ }^{\prime} \mathrm{P}<0.05$, vs. ethanol. (B) Dose-response investigation of ATG. PC12 cells were incubated with ethanol (500 mM) and ATG (0, 1, 5, $10,30,50$ and $100 \mu \mathrm{M})$ for 24 h. ATG $(5-30 \mu \mathrm{M})$ markedly promoted the proliferation of ethanol-treated cells (12-18\%). The most marked increase in cell viability was observed at an ATG concentration of $10 \mu \mathrm{M}$. Cell viability was examined using an MTT assay, and was calculated by cell proliferation index as a percentage of the value against the control group. ATG, arctigenin; OD, optical density.

ATG $(0,1,5,10,30,50$ and $100 \mu \mathrm{M})$ and $500 \mathrm{mM}$ ethanol for $24 \mathrm{~h}$, and cell viability was assessed using an MTT assay. Cells incubated with ethanol alone were used as a negative control. Incubation with ATG (5-30 $\mu \mathrm{M})$ promoted the viability of the ethanol-treated cells (12-18\%) and the ATG concentration of $10 \mu \mathrm{M}$ led to the most marked increase in cell viability. However, the concentration $>50 \mathrm{mM}$ had a contrasting effect (Fig. 2B). Therefore, an ATG concentration of $10 \mu \mathrm{M}$ effectively increased the viability of the ethanol-damaged cells and was used in the subsequent experiments.

ATG improves the proliferation index of ethanol-damaged cells. The proliferation status of cells is often evaluated using a proliferation index, which is calculated using the following formula: $(\mathrm{S}+\mathrm{G} 2 / \mathrm{M}) /(\mathrm{G} 0 / \mathrm{G} 1+\mathrm{S}+\mathrm{G} 2 / \mathrm{M})(18)$. To investigate the possible mechanism underlying the promoting effect of ATG on proliferation, FCM was used to detect the cell cycle. Following treatment for 24,48 and $72 \mathrm{~h}$ with $10 \mu \mathrm{M}$ ATG, $500 \mathrm{mM}$ ethanol, and $10 \mu \mathrm{M}$ ATG combined with $500 \mathrm{mM}$ ethanol, respectively, the cells were collected and incubated with PI. The FCM results showed that, compared with the ethanol-damaged group of cells, ATG significantly increased the number of cells in the $\mathrm{G} 2 / \mathrm{M}$ phase (Fig. 3A; $\mathrm{P}<0.05$ ), effectively promoted the proliferation of damaged cells, and significantly increased the distribution ratio of the cells at the G2/M and S phases (Fig. 3B).

ATG efficiently reduces the apoptosis and necrosis caused by ethanol. Following treatment of the cells with ethanol, the cell membrane was found to shrink and several apoptotic bodies were produced in the PC12 cells. To detect the apoptosis and necrosis of PC12 cells, the cells were stained with Hoechst33342 and PI following $48 \mathrm{~h}$ treatment with $10 \mu \mathrm{M}$ ATG, $500 \mathrm{mM}$ ethanol, and $500 \mathrm{mM}$ ethanol combined with $10 \mu \mathrm{M}$ ATG, respectively. Following staining, apoptotic cells were bright blue in color, whereas necrotic cells were red and normal cells were dark blue. The results showed that the apoptosis and necrosis of PC12 cells were significantly decreased following treatment with ATG (Fig. 4).
ATG significantly inhibits early apoptosis of ethanol-damaged cells. In order to detect the effects of ATG on apoptosis and necrosis in ethanol-damaged $\mathrm{PC} 12$ cells, the apoptotic rates of the PC12 cells and the protective effects of ATG were detected using Annexin V/PI staining and FCM, respectively. Using Annexin V/PI double staining, it was possible to separate normal cells (Annexin $\mathrm{V}^{-} / \mathrm{PI}^{-}$), early apoptotic cells (Annexin $\mathrm{V}^{+} / \mathrm{PI}^{-}$), late apoptotic and necrotic cell (Annexin $\mathrm{V}^{+} / \mathrm{PI}^{+}$). Following treatment with 24, 48 and $72 \mathrm{~h}$ with $10 \mu \mathrm{M}$ ATG, $500 \mathrm{mM}$ ethanol, and $10 \mu \mathrm{M}$ ATG combined with $500 \mathrm{mM}$ ethanol, respectively, the cells were collected and incubated with Annexin V-FITC and PI. The FCM results indicated that, compared with the control group, ethanol treatment significantly increased PC12 cell apoptosis, whereas apoptosis was significantly inhibited by the addition of ATG (Fig. 5A; $\mathrm{P}<0.05$ ), revealing a protective effect of ATG on ethanol-induced injured PC12 cells. The early apoptotic rate of the control cells was $\sim 0.23 \%$. Following incubation with ethanol fror $48 \mathrm{~h}$, the early apoptotic rate increased to $17.10 \%$. However, when treated with the ethanol and ATG together, the early apoptotic rate of the PC12 cells reduced to $3.57 \%$ (Fig. 5B).

\section{Discussion}

As a lipid-soluble and water-soluble substance, ethanol is rapidly absorbed in the body, and spreads to various organs and body fluids. Its metabolites and free radicals can cause a number of disorders and cytotoxic responses of the body's metabolism $(1,2)$. However, the mechanism underlying chronic ethanol-induced nervous system damage remains to be fully elucidated. It is generally considered to act in different ways, including the activation of GABA receptors, inhibition of NMDA glutamate receptors $(19,20)$, interference of $\mathrm{Na}^{+} / \mathrm{K}^{+}$, ATP enzymes and $\mathrm{Ca}^{2+}$ channels (21), and increasing the generation of reactive oxygen species causing apoptosis (22).

PC12 cells are from Rattus norvegicus adrenal tumors and are an ideal model for examining in vitro neurochemistry, neurobiology and nervous system diseases. Previous studies 


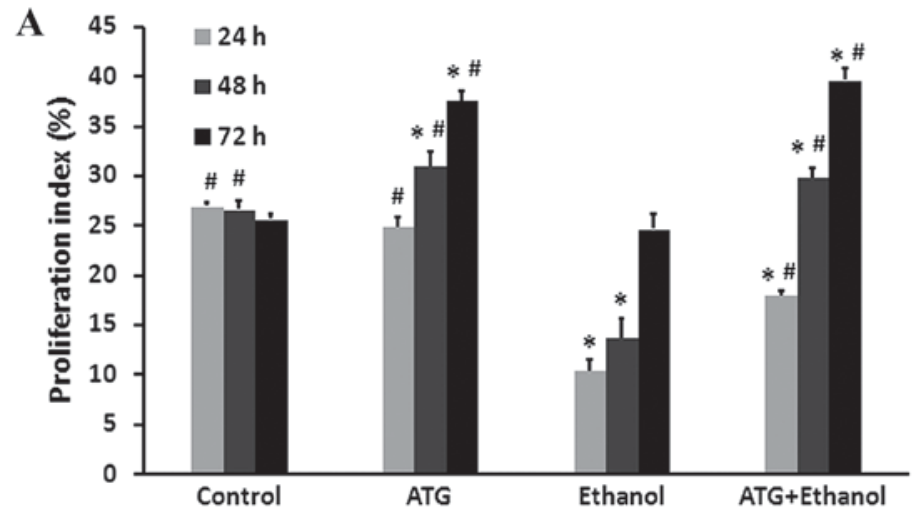

B
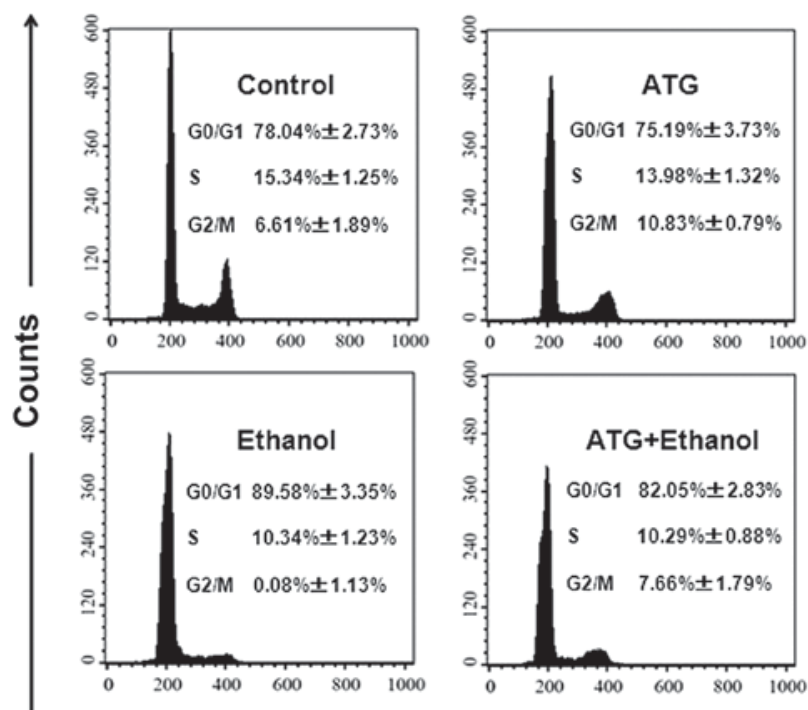

\section{FL2-H}

Figure 3. Cell cycle analysis. (A) Cell cycle analysis of different treatment groups at 24,48 and $72 \mathrm{~h}$. Data are presented as the mean \pm standard error of the mean from a minimum of three independent experiments, ${ }^{*} \mathrm{P}<0.05$, vs. control; ${ }^{*} \mathrm{P}<0.05$, vs. ethanol. (B) Cell cycle distribution was determined using FCM. Effects of ATG on ethanol-damaged PC12 cell G1 phase arrest. Following 24, 48 and $72 \mathrm{~h}$ treatment with $10 \mu \mathrm{M}$ ATG, $500 \mathrm{mM}$ ethanol, and $10 \mu \mathrm{M}$ ATG combined with $500 \mathrm{mM}$ ethanol, respectively, the PC12 cells were stained with propidium iodide and analyzed for DNA content using FCM. ATG, arctigenin; FCM, flow cytometry.
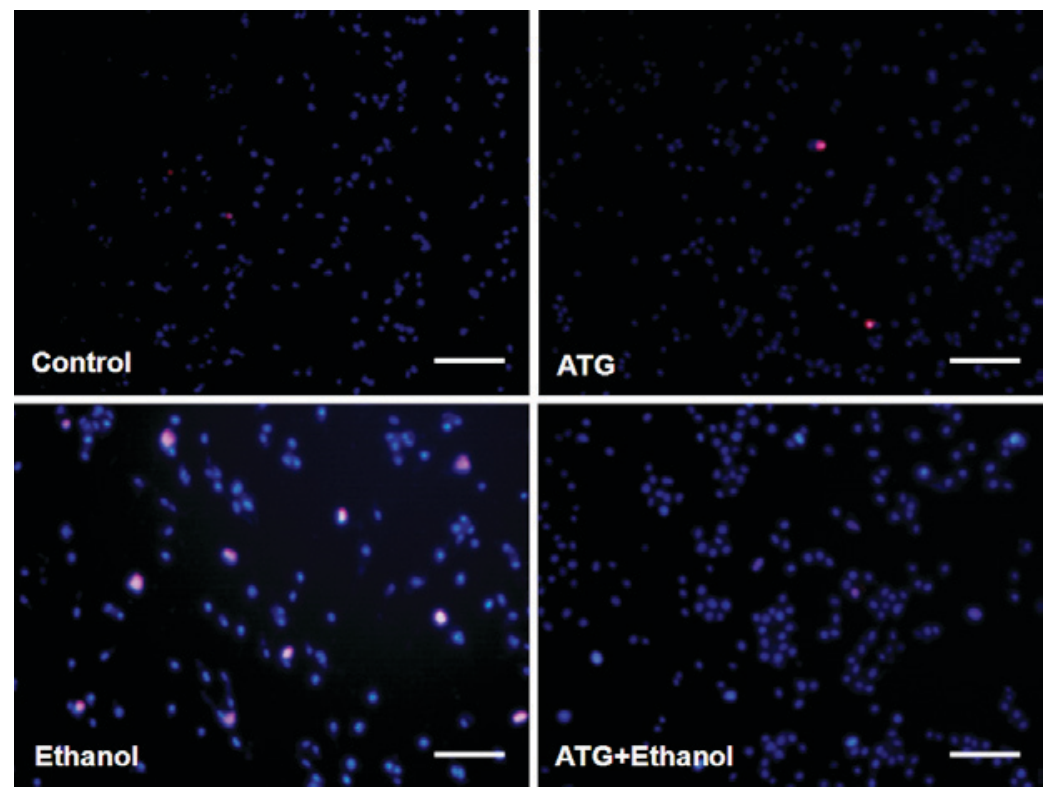

Figure 4. Representative fluorescence micrographs of Hoechst33342/PI staining. To detect the apoptosis and necrosis of PC12 cells, the cells were stained with Hoechst 33342 and PI following $48 \mathrm{~h}$ treatment with $10 \mu \mathrm{M}$ ATG, $500 \mathrm{mM}$ ethanol, and $500 \mathrm{mM}$ ethanol combined with $10 \mu \mathrm{M}$ ATG, respectively. Following staining, apoptotic cells were bright blue, necrotic cells were red and normal cells were dark blue. Scale bar=100 $\mu \mathrm{m}$ for all images. ATG, arctigenin; PI, propidium iodide. 

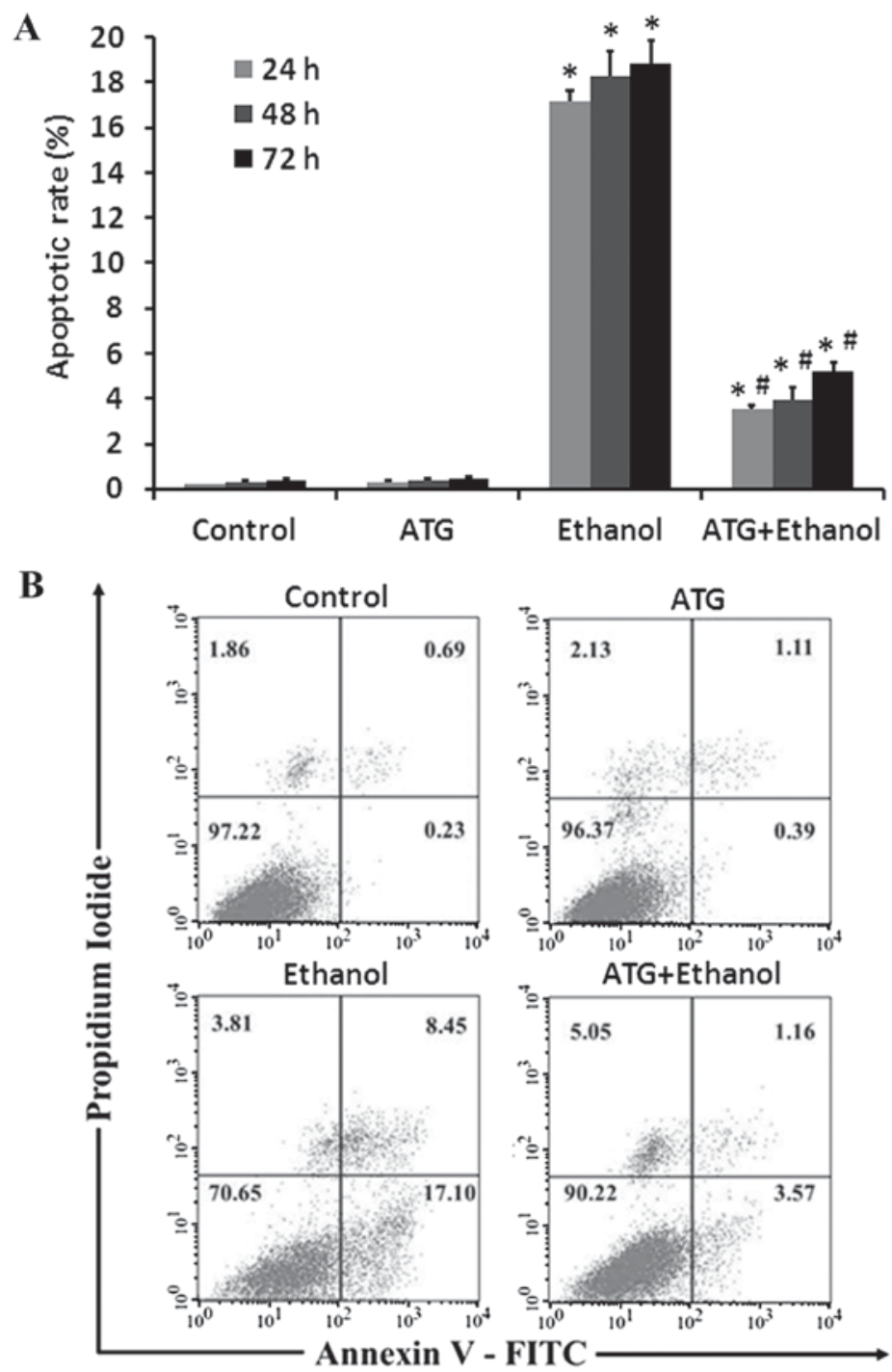

Figure 5. Effect of ATG on the apoptosis of ethanol-damaged PC12 cells. (A) Apoptotic rates of the differently treated PC12 cells at 24, 48 and $72 \mathrm{~h}$. Data are presented as the mean \pm standard error of the mean from a minimum of three independent experiments, ${ }^{*} \mathrm{P}<0.05$, vs. control; ${ }^{*} \mathrm{P}<0.05$, vs. ethanol. (B) Apoptotic rates of the differently treated PC12 cells at $48 \mathrm{~h}$. Following 24, 48 and $72 \mathrm{~h}$ treatment with ATG, PC12 cells were stained using PI and Annexin V-FITC. Cells were then analyzed using flow cytometry. ATG, arctigenin; PI, propidium iodide; FITC, fluorescein isothiocyanate.

have demonstrated that chronic ethanol exposure can inhibit the proliferation of cultured PC12 cells (23) and promote the apoptosis of PC12 cells by affecting the protein expression of B-cell lymphoma 2 and Caspase-3 (24). Therefore, promoting nerve cell proliferation or inhibiting apoptosis may be an effective treatment for ethanol-induced neurotoxicity.

The use of a single natural active ingredient of a traditional Chinese medicine to promote proliferation and inhibit apoptosis has increased in popularity. As a natural medicine, ATG exerts several bioactivities and a number of important pharmacological properties, including antioxidant, antitumor, anti-inflammatory and immunomodulatory effects (10-14). Studies have found that ATG has a neuroprotective effect on cultured cortical neurons from glutamate-induced neurodegeneration and acts on mice with scopolamine-induced memory deficit through mechanisms, which remain to be fully elucidated $(15,16)$. ATG has been found to have protective effects on a selective pharmacological protein kinase A inhibitor in H89-induced neuronal injury in rats (15). In addition, a previous study provided evidence that ATG can inhibit the synthesis of $\beta$-amyloid and accelerate its degradation, which was found to improve memory impairment in mice with Alzheimer's disease (16). However, the protective effect of ATG on ethanol-induced neurotoxicity remains to be fully elucidated.

In the present study, in order to investigate the protective effect of ATG on alcohol-induced neurotoxicity and apoptosis in rat pheochromocytoma PC12 cells, a cell model of ethanol damage was first established using ethanol $(500 \mathrm{mM})$ in a series of doses in preliminary experiments, which induced significant apoptosis of the PC12 cells. Subsequently, a variety of detection methods were used to investigate whether ATG had a protective effect on ethanol-induced neurotoxicity in PC12 cells. The results showed that ATG at a concentration of $10 \mu \mathrm{M}$ significantly promoted the proliferation of damaged cells, reduced the proportion of cells in the G0/G1 phase and increased the cell proliferation index. Following exposure of the cells to $500 \mathrm{mM}$ ethanol, the number of cells was reduced and a substantial number of apoptotic bodies were formed. Data from the FCM analysis indicated that 
$10 \mu \mathrm{M}$ ATG significantly reduced apoptosis and necrosis in the ethanol-treated cells. This experiment demonstrated that ATG reduced the ability of a high concentration of ethanol to inhibit well-differentiated PC12 cells, the specific mechanism of which requires further investigation $(25,26)$.

In conclusion, the data obtained in the present study indicated that ATG at a concentration of $10 \mu \mathrm{M}$ increased the distribution ratio of the damaged cells at the $\mathrm{G} 2 / \mathrm{M}$ and $\mathrm{S}$ phases, and significantly reduced apoptosis and necrosis in ethanol-treated cells. Therefore, it was concluded that ATG had a protective effect on the ethanol-damaged PC12 cells. The results of the present study provide a novel theoretical basis and therapeutic strategy for ATG in the clinical treatment of ethanol-induced neurotoxicity and damage.

\section{Acknowledgements}

This study was supported by the Innovative Research Team Development Program in University of Chongqing (grant no. CXTDX201601031), the Top Innovative Talents Training Fund for College Students from Chongqing University of Technology (grant nos. BC201305 and BC201409) and the Undergraduate Training Programs for Innovation and Entrepreneurship of Chongqing University of Technology (grant no. 2014CX03).

\section{References}

1. Baker RC and Kramer RE: Cytotoxicity of short-chain ethanols. Annu Rev Pharmacol Toxicol 39: 127-150,1999.

2. Smith AM, Zeve DR, Dohrman DP and Chen WJ: The interactive effect of alcohol and nicotine on NGF-treated pheochromocytoma cells. Alcohol 39: 65-72, 2006.

3. Grant BF, Dawson DA, Stinson FS, Chou SP, Dufour MC and Pickering RP: The 12-month prevalence and trends in DSM-IV alcohol abuse and dependence: United States, 1991-1992 and 2001-2002. Drug Alcohol Depend 74: 223-234, 2004.

4. World Health Organization: Global status report on alcohol and health. Geneva, Switzerland: World Health Organization, 2014.

5. Heaton MB, Paiva M, Madorsky I and Shaw G: Ethanol effects on neonatal rat cortex: Comparative analyses of neurotrophic factors, apoptosis-related proteins, and oxidative processes during vulnerable and resistant periods. Brain Res Dev Brain Res 145: 249-262, 2003

6. Dikranian K, Qin YQ, Labruyere J, Nemmers B and Olney JW: Ethanol-induced neuroapoptosis in the developing rodent cerebellum and related brain stem structures. Brain Res Dev Brain Res 155: 1-13, 2005.

7. Green CR, Kobus SM, Ji Y, Bennett BM, Reynolds JN and Brien JF: Chronic prenatal ethanol exposure increases apoptosis in the hippocampus of the term fetal guinea pig. Neurotoxicol Teratol 27: 871-881, 2005.

8. Jonas DE, Amick HR, Feltner C, Bobashev G, Thomas K, Wines R, Kim MM, Shanahan E, Gass CE, Rowe CJ and Garbutt JC: Pharmacotherapy for adults with alcohol use disorders in outpatient settings: A systematic review and meta-analysis. JAMA 311: 1889-1900, 2014.
9. Ojehagen A, Skjaerris A and Berglund M: Long-term use of aversive drugs in outpatient alcoholism treatment. Acta Psychiatr Scand 84: 185-190, 1991.

10. Hirano T, Gotoh M and Oka K: Natural flavonoids and lignansare potent cytostatic agents against human leukemic HL-60 cells. Life Sci 55: 1061-1069, 1994.

11. Umehara K, Nakamura M, Miyase T, Kuroyanagi M and Ueno A: Studies on differentiation inducers VI. Lignan derivatives from Arctium fructus. (2). Chem Pharm Bull (Tokyo) 44: 2300-2304, 1996.

12. Cho JY, Kim AR, Yoo ES, Baik KU and Park $\mathrm{MH}$ : Immunomodulatory effect of arctigenin, a lignan compound, on tumor necrosis factor and nitric oxide production, and lymphocyte proliferation. J Pharm Pharmacol 51: 1267-1273, 1999.

13. Wu JG, Wu JZ, Sun LN, Han T, Du J, Ye Q, Zhang H and Zhang YG: Ameliorative effects of arctiin from Arctium lappa on experimental glomerulonephritis in rats. Phytomedicine 16: 1033-1041, 2009.

14. Zhao F, Wang L and Liu K: In vitro anti-inflammatory effects of arctigenin, alignan from Arctium lappa L., through inhibition on iNOS pathway. J Ethnopharmacol 122: 457-462, 2009.

15. Zhang N, Wen Q, Ren L, Liang W, Xia Y, Zhang X, Zhao D, Sun D, Hu Y, Hao H, et al: Neuroprotective effect of arctigenin via upregulation of P-CREB in mouse primary neurons and human SH-SY5Y neuroblastoma cells. Int J Mol Sci 14: 18657-18669, 2013.

16. Zhu Z, Yan J, Jiang W, Yao XG, Chen J, Chen L, Li C, Hu L, Jiang $\mathrm{H}$ and Shen $\mathrm{X}$ : Arctigenin effectively ameliorates memory impairment in Alzheimer's disease model mice targeting both $\beta$-amyloid production and clearance. J Neurosci 33: 13138-13149, 2013.

17. Adickes ED, Mollner TJ and Lockwood SK: Closed chamber system for delivery of ethanol to cell cultures. Alcohol Alcohol 23: 377-381, 1988.

18. Wang M, Shen J, Feng B, Gui L, Chen Q, Zhang B, Tang J and Li X: Remote ischemic preconditioning promotes early liver cell proliferation in a rat model of small-for-size liver transplantation. J Surg Res 179: e245-e253, 2013.

19. Moonat S, Starkman BG, Sakharkar A and Pandey SC: Neuroscience of ethanolism: Molecular and cellular mechanisms. Cell Mol Life Sci 67: 73-88, 2010.

20. Ramezani A, Goudarzi I, Lashkarboluki T, Ghorbanian MT, Abrari K and Elahdadi Salmani M: Role of oxidative stress in ethanol-induced neurotoxicity in the developing cerebellum. Iran J Basic Med Sci 15: 965-974, 2012.

21. Ramachandran V, Watts LT, Maffi SK, Chen J, Schenker S and Henderson G: Ethanol-induced oxidative stress precedes mitochondrially mediated apoptotic death of cultured fetal cortical neurons. J Neurosci Res 74: 577-588, 2003.

22. Pettus BJ, Chalfant CE and Hannun YA: Ceramide in apoptosis: An overview and current perspectives. Biochim Biophys Acta 1585: 114-125, 2002.

23. Pantazis NJ, Dohrman DP, Luo J, Goodlett CR and West JR Ethanol reduces the number of pheochromocytoma (PC12) cells in culture. Alcohol 9: 171-180, 1992.

24. Hong F, Kim WH, Tian Z, Jaruga B, Ishac E, Shen X and Gao B: Elevated interleukin-6 during ethanol consumption acts as a potential endogenous protective cytokine against ethanol-induced apoptosis in the liver: Involvement of induction of Bcl-2 and Bcl-x(L) proteins. Oncogene 21: 32-43, 2002.

25. Messing RO, Henteleff $M$ and Park JJ: Ethanol enhances growth factor-induced neurite formation in PC12 cells. Brain Res 565: 301-311, 1991.

26. Wooten MW and Ewald SJ: Ethanols synergize with NGF to induce early differentiation of PC12 cells. Brain Res 550: 333-339, 1991. 